\title{
Physicochemical characteristics and sensory profile of honey samples from stingless bees (Apidae: Meliponinae) submitted to a dehumidification process
}

\author{
CARlos A.l. CARVAlHo ${ }^{1}$, GeNi S. SODRÉ ${ }^{1}$, ANTONiO A.O. FONSECA ${ }^{1}$, ROGÉrio M.O. ALVES ${ }^{1}$, \\ BRUNO A. SOUZA ${ }^{2}$ and LANA CLARTON ${ }^{1}$ \\ ${ }^{1}$ Centro de Ciências Agrárias, Ambientais e Biológicas, Universidade Federal do Recôncavo da Bahia, \\ Caixa Postal 118, 44380-000 Cruz das Almas, BA, Brasil \\ ${ }^{2}$ Embrapa Meio-Norte, Núcleo de Pesquisas com Abelhas, Av. Duque de Caxias, 5.650, Buenos Aires \\ 64006-220 Teresina, PI, Brasil \\ Manuscript received on March 14, 2008; accepted for publication on September 17, 2008, \\ presented by ELIBIO L. RECH
}

\begin{abstract}
This study was conducted to evaluate the effect of a dehumidification process on the physicochemical and sensory characteristics of stingless-bee honey. Melipona scutellaris and M. quadrifasciata honey samples were submitted to a dehumidification process and to physicochemical (reducing sugars, apparent sucrose, moisture, diastatic activity, hydroxymethylfurfural, ash, pH, acidity, and electric conductivity) and sensory evaluations (fluidity, color, aroma, crystallization, flavor, and acceptability). The results indicated that the dehumidification process does not interfere with honey quality and acceptability.
\end{abstract}

Key words: honey conservation, meliponids, honey quality, moisture.

\section{INTRODUCTION}

Honey is the most important product of stingless bees (meliponines), consisting basically of a complex mixture of carbohydrates, especially glucose and fructose, organic acids, amino acids, minerals, vitamins, enzymes, pollens, and pigments (Crane 1987, Fallico et al. 2004). Its nutritional quality, medicinal, and sensory properties have attracted thousands of consumers. However, worldwide and domestic meliponiculture has faced great difficulties with regard to the conservation of this product, due to its high moisture content, resulting in fermentation and consequent deterioration.

The processes that are normally employed in the preservation of food products have the main objective of maintaining their health, organoleptic, and nutritional

Correspondence to: Carlos Alfredo Lopes de Carvalho E-mail: calfredo@ufrb.edu.br qualities for the longest time possible (Silva 2000), minimizing alterations related to the presence of microorganisms that develop in environments with nutritious and favorable conditions, according to the microbial species (Gava 1998).

According to White Júnior (1978), certain osmophilic yeasts, when present in honey, multiply as moisture increases, facilitating the fermentation process. These microorganisms are present in the body of bees, in nectar, in the soil, and in honey extraction and storage areas.

Honey stored at an adequate moisture content is unquestionably a guaranteed and extremely durable product, which can be exposed on store shelves without problem until consumption (Moraes et al. 1989).

Considering the difficulty faced by stingless bee keepers with regard to honey conservation owing to its high moisture content, the dehumidification process 
emerges as a promising alternative. Therefore, this work aimed to evaluate the physicochemical and sensory characteristics of honey samples from stingless bees, submitted to the process of dehumidification.

\section{MATERIALS AND METHODS}

The experiment was conducted in the Entomology Laboratory of Centro de Ciências Agrárias, Ambientais e Biológicas at Universidade Federal do Recôncavo da Bahia, in Cruz das Almas, Bahia, Brazil.

Honey samples from stingless bees Melipona scutellaris and $M$. quadrifasciata were used due to the great honey-producing potential of these species and their importance in family agriculture programs in the Northeast region of Brazil.

\section{Collection of SAMPles}

M. scutellaris honey came from the Itaparica Island and from Costa do Sauípe, in the coastal region of the State of Bahia, Brazil, while M. quadrifasciata honey came from Tucano and Serrinha, in the Semi-Arid region of the State of Bahia, Brazil. A sample was obtained for each locality, consisting of $1,000 \mathrm{~mL}$ of honey collected with a suction pump or a disposable syringe, directly from closed pots of colonies installed in INPA-model rational hives, during the months of December 2005 and January 2006, the period when major blooms occur in those regions.

The honey thus collected was stored in previously sterilized and hermetically sealed glass jars. The jars were placed in a Styrofoam box containing ice and then transported to the laboratory on the same day the honey was collected, and were stored under refrigeration at $8^{\circ} \mathrm{C}$. Two sub-samples were obtained for each sample: one was used as control (fresh) and the other was submitted to the dehumidification process, totaling eight subsamples.

\section{DEHUMIDIFICATION PROCESS}

A BOD incubator (Biological Oxygen Demand) (ELETROLAB brand, model $122 \mathrm{~F}$ ) with temperature control was used for honey dehumidification, at temperature of $35.5^{\circ} \mathrm{C}$; moisture inside the BOD chamber was adjusted with silica gel and monitored with a thermohygrometer.
The silica gel was replaced daily due to moisture absorption from the environment.

When incubator moisture was at approximately $40 \%$, non-toxic plastic trays containing the honey subsamples were distributed on the shelves inside the BOD chamber to be exposed to the controlled environment conditions.

Moisture in the various honey samples was determined before and during the dehumidification process using a honey-specific ATAGO refractometer, until a moisture value of approximately $17 \%$ was achieved, after five days of exposure, on average.

\section{Physicochemical Analyses}

Determinations were made in each sub-sample for reducing sugars (\%), apparent sucrose (\%) (C.A.C. 1990), moisture (ATAGO Co. 1988), diastatic activity (C.A.C. 1990), hydroxymethylfurfural (AOAC 1990), ash (Pregnolato and Pregnolato 1985), pH (Moraes and Teixeira 1998), acidity (AOAC 1990), and electric conductivity (B.O.E. 1986).

\section{SENSORY EVALUATION}

The sensory evaluation was performed by 30 untrained panelists of both sexes, with ages ranging between 20 and 50 years, including students, employees, and professors of Universidade Federal do Recôncavo da Bahia in Cruz das Almas. The sub-samples were coded with three-digit numbers and were served at room temperature, arranged in plastic cups containing approximately $10 \mathrm{~g}$. Mineral water and salt crackers were supplied as palate cleansers between sample evaluations (Ferreira 2000). Tests were carried out between 0900 and 1200 hours and from 1400 to 1700 hours. We adopted the methodology of Grosso (2006), which was used as basis for the following evaluations: fluidity, color, aroma, crystallization, flavor, and acceptability.

\section{DATA ANALYSIS}

The data were submitted to analysis of variance (ANOVA), Tukey's Test at 5\% significance for comparisons between means, and Principal Components Analysis (PCA). A sensory profile analysis of the samples was conducted using spider charts. 
TABLE I

Mean values for physicochemical parameters of Melipona scutellaris (MS) and Melipona quadrifasciata (MQ) honey, either fresh or submitted to a dehumidification process.

\begin{tabular}{|c|c|c|c|c|c|c|c|c|c|}
\hline \multirow{2}{*}{$\begin{array}{c}\text { Species / } \\
\text { treatments / } \\
\text { localities / }\end{array}$} & \multicolumn{9}{|c|}{ Characteristics evaluated } \\
\hline & $\begin{array}{l}\mathrm{M} \\
\%\end{array}$ & $\begin{array}{c}\mathrm{RS} \\
\%\end{array}$ & $\begin{array}{c}\mathrm{AS} \\
\%\end{array}$ & $\begin{array}{c}\text { HMF } \\
\text { mg.kg-1 }\end{array}$ & $\begin{array}{c}\text { DA } \\
\text { Gothe }\end{array}$ & $\mathrm{pH}$ & $\begin{array}{c}\text { Acidity } \\
\text { meq.kg-1 }\end{array}$ & $\begin{array}{l}\text { Ash } \\
(\%)\end{array}$ & $\begin{array}{c}\mathrm{EC} \\
\mu \mathrm{S} . \mathrm{cm}^{-1}\end{array}$ \\
\hline $\mathrm{MS} / \mathrm{C} / \mathrm{II}$ & $>30.00^{\mathrm{a}}$ & $53.91^{f}$ & $1.11^{\mathrm{d}}$ & $2.21^{\mathrm{d}}$ & $2.16^{\mathrm{b}}$ & $3.53^{\mathrm{cd}}$ & $55.00^{\mathrm{a}}$ & $0.1822^{\mathrm{cd}}$ & $272.10^{\mathrm{d}}$ \\
\hline $\mathrm{MS} / \mathrm{D} / \mathrm{II}$ & $16.00^{\mathrm{c}}$ & $67.57^{\mathrm{c}}$ & $1.51^{\mathrm{c}}$ & $6.65^{\mathrm{a}}$ & $1.73^{b}$ & $3.71^{\mathrm{c}}$ & $53.50^{\mathrm{b}}$ & $0.1835^{\mathrm{c}}$ & $289.90^{\mathrm{c}}$ \\
\hline $\mathrm{MS} / \mathrm{C} / \mathrm{CS}$ & $26.00^{b}$ & $56.98^{e}$ & $3.17^{\mathrm{b}}$ & $1.33^{\mathrm{e}}$ & $3.01^{\mathrm{a}}$ & $3.57^{\mathrm{cd}}$ & $25.75^{d}$ & $0.1794^{\mathrm{d}}$ & $264.20^{\mathrm{e}}$ \\
\hline $\mathrm{MS} / \mathrm{D} / \mathrm{CS}$ & $16.50^{\mathrm{c}}$ & $70.92^{b}$ & $4.35^{\mathrm{a}}$ & $3.02^{\mathrm{c}}$ & $2.18^{\mathrm{b}}$ & $3.67^{\mathrm{cd}}$ & $28.50^{\mathrm{c}}$ & $0.1714^{\mathrm{e}}$ & $271.60^{d}$ \\
\hline $\mathrm{MQ} / \mathrm{C} / \mathrm{TU}$ & $25.20^{\mathrm{b}}$ & $60.42^{\mathrm{d}}$ & $1.28^{\mathrm{d}}$ & $1.27^{\mathrm{e}}$ & $1.40^{\mathrm{c}}$ & $6.64^{\mathrm{a}}$ & $6.25^{\mathrm{f}}$ & $0.3925^{\mathrm{b}}$ & $445.95^{b}$ \\
\hline $\mathrm{MQ} / \mathrm{D} / \mathrm{TU}$ & $16.90^{\mathrm{c}}$ & $72.99^{a}$ & $2.52^{b}$ & $3.82^{b}$ & $1.34^{\mathrm{c}}$ & $6.04^{\mathrm{b}}$ & $7.50^{\mathrm{e}}$ & $0.4054^{\mathrm{a}}$ & $596.80^{\mathrm{a}}$ \\
\hline $\mathrm{MQ} / \mathrm{C} / \mathrm{SE}$ & $>30.00^{\mathrm{a}}$ & $60.06^{\mathrm{d}}$ & $1.32^{\mathrm{d}}$ & $1.45^{\mathrm{e}}$ & $2.14^{b}$ & $3.74^{\mathrm{c}}$ & $28.00^{c}$ & $0.1456^{\mathrm{f}}$ & $226.00^{f}$ \\
\hline $\mathrm{MQ} / \mathrm{D} / \mathrm{SE}$ & $17.00^{\mathrm{c}}$ & $74.63^{a}$ & $2.96^{\mathrm{b}}$ & $4.39^{b}$ & $1.65^{b}$ & $3.46^{\mathrm{d}}$ & $28.50^{c}$ & $0.1238^{\mathrm{g}}$ & $217.10^{\mathrm{g}}$ \\
\hline
\end{tabular}

$\mathrm{C}=$ control (fresh), $\mathrm{D}=$ dehumidified, $\mathrm{II}=$ Itaparica Island, $\mathrm{CS}=$ Costa do Sauípe, $\mathrm{TU}=$ Tucano, $\mathrm{SE}=\mathrm{Serrinha}, \mathrm{M}=$ moisture, $\mathrm{RS}=$ reducing sugars, $\mathrm{AS}=$ apparent sucrose, $\mathrm{HMF}=$ hydroxymethylfurfural, $\mathrm{DA}=$ diastatic activity, EC = electric conductivity. Means followed by the same letter, in the same column, do not differ by Tukey's test at the 5\% significance level.

\section{RESULTS AND DISCUSSION}

\section{PhysicochemicAl ANALYSES}

The physicochemical analysis results of M. scutellaris and M. quadrifasciata fresh and dehumidified honey samples are presented in Table I.

There were significant differences between the characteristics evaluated in honey samples of both bee species from various localities, and also with regard to the treatment used. According to Carvalho et al. (2006), honey composition may vary depending on the flora, location, harvest season, management, and especially the bee species that produced the honey (Table I).

The significant differences obtained for moisture between the control and the treatment were expected, because of honey water loss caused by the dehumidification process, which reduced moisture to approximately $17 \%$. Such high moisture present in honey produced by stingless bees is a major hindrance to meliponiculture. Hence, dehumidification emerges as an important step in the conservation of this product, preventing losses by deterioration due to fermentation.

Significant statistical differences were also observed for reducing sugars and apparent sucrose. These differences occurred because of the water loss resulting from dehumidification, with a consequent concentration of sugars.
Statistical differences were observed between the treatments and the controls for hydroxymethylfurfural in the various samples analyzed (Table I). These differences could be related to an increase in honey concentration caused by water loss, in addition to a possible effect of honey exposure to a temperature of $35.5^{\circ} \mathrm{C}$. Although the HMF value increased, it did not interfere with final product quality, as those values were still well below the maximum value accepted by Brazilian law (Brasil 2000).

The diastatic activity in the various honey samples showed statistical difference, and treatment values below those found for the controls were observed, probably because of exposure to high temperature during dehumidification. The diastase enzyme is very sensitive to heat, and is recommended to evaluate honey quality, providing indications about the honey's degrees of conservation and overheating, which seriously compromise the product (Soloveve 1971). In most stingless bee honeys, diastatic activity values are smaller than the minimum value established for honey by Brazilian law (Brasil 2000). The use of diastatic activity as honey quality indicator has been questioned by White Júnior (1994), since the amount of this enzyme in freshly-harvested and unheated honey varies quite a bit.

Statistical differences were also observed between the treatment and the control for $\mathrm{pH}$, acidity, ash, and 
TABLE II

Variance estimates (eigenvalues), contribution percentage, and cumulative contribution (\%), obtained by Principal

Components Analysis, considering physicochemical characteristics of fresh and dehumidified honey of two stingless bee species.

\begin{tabular}{c|c|c|c}
\hline $\begin{array}{c}\text { Principal } \\
\text { components }\end{array}$ & Eigenvalues & \% contribution & $\begin{array}{c}\% \text { cumulative } \\
\text { contribution }\end{array}$ \\
\hline 1 & 4.08 & 45.38 & 45.38 \\
\hline 2 & 2.89 & 32.18 & 77.56 \\
\hline
\end{tabular}

TABLE III

Contribution toward the formation of the principal component of physicochemical characteristics of fresh and dehumidified honey of two stingless bee species.

\begin{tabular}{l|c|c}
\hline \multirow{2}{*}{ Characteristics analyzed } & \multicolumn{2}{|c}{ Principal components } \\
\cline { 2 - 3 } & 1 & 2 \\
\hline Moisture & 0.044580 & $\mathbf{0 . 2 7 1 4 9 2}$ \\
\hline Reducing sugar & 0.055552 & 0.240176 \\
\hline Apparent sucrose & 0.000147 & 0.107595 \\
\hline Hydroxymethylfurfural & 0.003728 & 0.240913 \\
\hline Diastatic activity & 0.150387 & 0.013450 \\
\hline pH & 0.204647 & 0.050339 \\
\hline Acidity & 0.131665 & 0.021335 \\
\hline Ash & 0.201911 & 0.043420 \\
\hline Electric conductivity & $\mathbf{0 . 2 0 7 3 8 3}$ & 0.011279 \\
\hline
\end{tabular}

electric conductivity. However, these did not interfere with product quality (Brasil 2000).

Tables II and III and Figure 1 present the principal components analysis results (PCA) relative to the physicochemical analyses of the samples studied. In the PCA graphic representation, each axis (principal component) explains a percentage of total contribution between the samples.

In the samples, the relationships between physicochemical characteristics (Tables II and III) produced contribution percentages of $45.38 \%$ for the first component and $32.18 \%$ for the second component, explaining $77.56 \%$ of the total variation that existed between samples. According to Mardia et al. (1979), when in a PCA the first two or three components accumulate a relatively high percentage of total variation, in general above $70 \%$, they would satisfactorily explain the variability manifested between the samples. In the present study, the cumulative percentages of total variation $(77.56 \%)$ demonstrated an excellent explanation of the variation between samples.

From the data in Figure 2 concerning the PCA for physicochemical characteristics, it can be seen that the first principal component suggests similarity between the samples studied, with the formation of two distinct groups: the first comprising dehumidified samples, above the $\mathrm{X}$ axis (principal component 1), and the second comprising control samples, below the $\mathrm{X}$ axis (principal component 1). An analysis of both groups formed on the $\mathrm{X}$ axis shows that one sample in each group formed (5 and 6) departed from the others and was to the left of axis $\mathrm{X}$, probably because it had a higher electric conductivity value, the physicochemical trait that contributed the most towards the formation of groups (Table III).

An analysis of the second principal component, on the $Y$ axis, shows that samples 2, 4, and 8 stand out because they are located well above the others. These samples are all dehumidified. The trait that contributed the most toward the formation of groups in principal component 2 was moisture (physicochemical). The greatest interference in the honey dehumidification process was caused by this parameter owing to water loss. Sample 6, also dehumidified, departed from the others probably because of its high electric conductivity value (Table I), the parameter that most influenced the formation of groups (principal component 1 - explaining 45\%).

\section{SENSORY EVALUATION}

The sensory evaluation and acceptability results for $M$. scutellaris and M. quadrifasciata honey, either fresh or submitted to dehumidification can be observed in Table IV and Figure 3.

No statistical difference was seen at the 5\% level in the evaluations for honey crystallization, flavor, aroma, and acceptability, indicating that the dehumidification process did not interfere with these attributes.

No statistical difference was verified for the color attribute between the treatment (dehumidification) and the control (fresh honey) in the same sample. However, there was statistical difference between some of the various honey samples (bee species/localities). This can be explained by the fact that honey characteristics are 


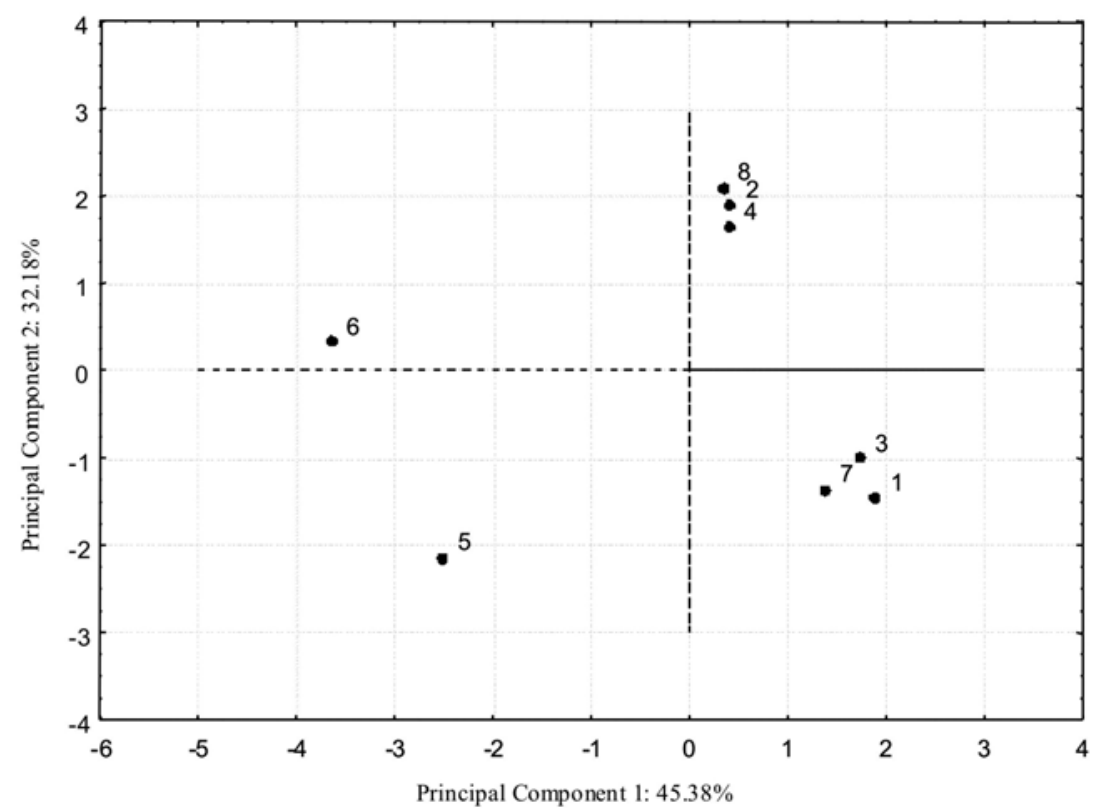

Fig. 1 - Bidimensional projection of principal components analysis for physicochemical characteristics of fresh or dehumidified honey of two stingless bee species from four localities of the State of Bahia, Brazil: 1) Melipona scutellaris - fresh/Itaparica Island, 2) M. scutellaris Dehumidified/Itaparica Island, 3) M. scutellaris - fresh/Costa do Saúpe, 4) M. scutellaris - Dehumidified/Costa do Sauípe, 5) M. quadrifasciata fresh/Tucano, 6) M. quadrifasciata - Dehumidified/Tucano, 7) M. quadrifasciata - fresh/Serrinha, 8) M. quadrifasciata - Dehumidified/Serrinha.

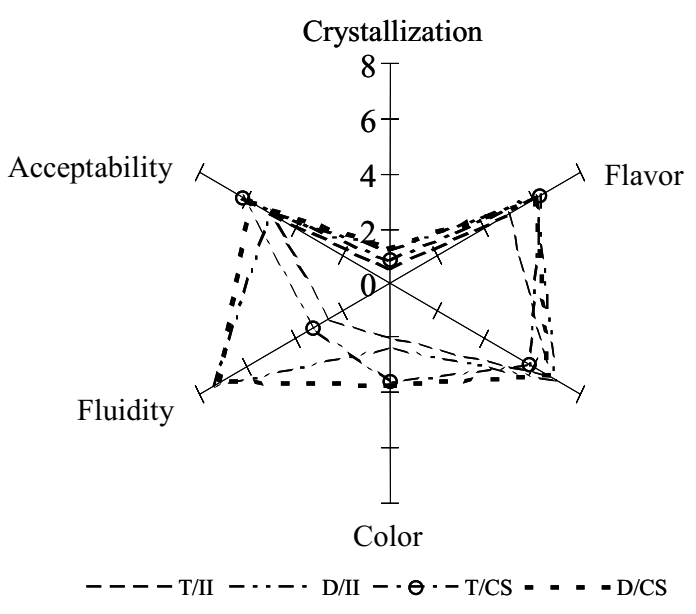

Melipona scutellaris

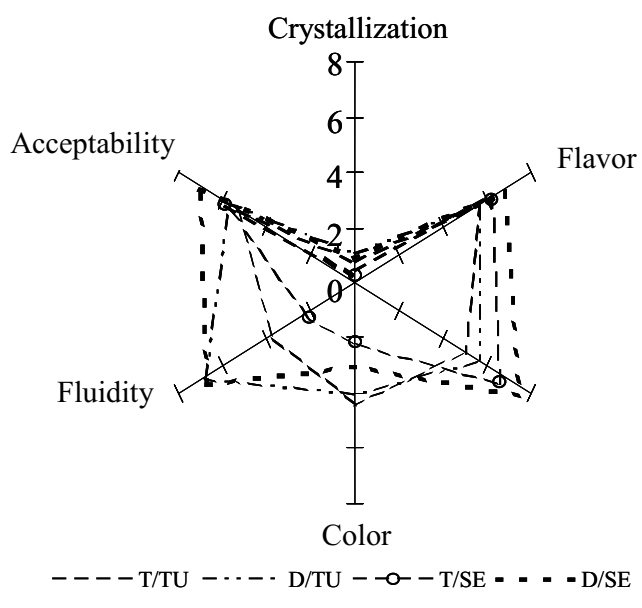

Melipona quadrifasciata

Fig. 2 - Sensory profile of honey samples of Melipona scutellaris (MS) and Melipona quadrifasciata (MQ), either fresh or submitted to a dehumidification process. Legend: T - control (fresh); D - dehumidified; II - Itaparica Island; CS - Costa do Sauípe; TU - Tucano; SE - Serrinha.

differentiated by several factors, including bee species, botanical source, and climatic and edaphic conditions at the location where the honey was produced.

With respect to sample fluidity evaluation, statistical differences were observed between the treatment and the control when the samples of each species were evaluated separately. The dehumidification treatment applied to the samples removed moisture from the honey making it denser and imparting higher ratings for this attribute, which is an expected result. 
TABLE IV

Mean values for sensory attributes found in honey samples of Melipona scutellaris (MS) and Melipona quadrifasciata (MQ), either fresh or submitted to a dehumidification process.

\begin{tabular}{c|c|c|c|c|c|c}
\hline \multirow{2}{*}{$\begin{array}{c}\text { Species } / \\
\text { treatments } \\
\text { location }\end{array}$} & Crystallization & Flavor & Aroma & Color & Fluidity & Acceptability \\
\cline { 2 - 7 } MS/C/II & $0.54^{\mathrm{a}}$ & $5.00^{\mathrm{a}}$ & $6.69^{\mathrm{ab}}$ & $1.92^{\mathrm{c}}$ & $2.65^{\mathrm{bc}}$ & $5.04^{\mathrm{a}}$ \\
\hline $\mathrm{MS} / \mathrm{D} / \mathrm{II}$ & $1.23^{\mathrm{a}}$ & $6.12^{\mathrm{a}}$ & $6.92^{\mathrm{a}}$ & $2.35^{\mathrm{c}}$ & $7.46^{\mathrm{a}}$ & $5.08^{\mathrm{a}}$ \\
\hline $\mathrm{MS} / \mathrm{C} / \mathrm{CS}$ & $0.85^{\mathrm{a}}$ & $6.27^{\mathrm{a}}$ & $5.81^{\mathrm{ab}}$ & $3.58^{\mathrm{ab}}$ & $3.19^{\mathrm{bc}}$ & $6.19^{\mathrm{a}}$ \\
\hline $\mathrm{MS} / \mathrm{D} / \mathrm{CS}$ & $1.27^{\mathrm{a}}$ & $6.08^{\mathrm{a}}$ & $6.62^{\mathrm{ab}}$ & $3.69^{\mathrm{ab}}$ & $7.12^{\mathrm{a}}$ & $5.85^{\mathrm{a}}$ \\
\hline $\mathrm{MQ} / \mathrm{C} / \mathrm{TU}$ & $0.77^{\mathrm{a}}$ & $5.62^{\mathrm{a}}$ & $4.96^{\mathrm{a}}$ & $4.42^{\mathrm{a}}$ & $3.73^{\mathrm{b}}$ & $5.31^{\mathrm{a}}$ \\
\hline $\mathrm{MQ} / \mathrm{D} / \mathrm{TU}$ & $1.08^{\mathrm{a}}$ & $5.62^{\mathrm{a}}$ & $5.65^{\mathrm{ab}}$ & $4.00^{\mathrm{a}}$ & $6.85^{\mathrm{a}}$ & $5.69^{\mathrm{a}}$ \\
\hline $\mathrm{MQ} / \mathrm{C} / \mathrm{SE}$ & $0.46^{\mathrm{a}}$ & $6.23^{\mathrm{a}}$ & $6.54^{\mathrm{ab}}$ & $1.90^{\mathrm{c}}$ & $2.00^{\mathrm{c}}$ & $5.88^{\mathrm{a}}$ \\
\hline $\mathrm{MQ} / \mathrm{D} / \mathrm{SE}$ & $1.08^{\mathrm{a}}$ & $6.81^{\mathrm{a}}$ & $7.46^{\mathrm{a}}$ & $2.77^{\mathrm{bc}}$ & $6.69^{\mathrm{a}}$ & $6.96^{\mathrm{a}}$ \\
\hline
\end{tabular}

$\mathrm{C}=$ control (fresh), $\mathrm{D}=$ dehumidified, $\mathrm{II}=$ Itaparica Island, $\mathrm{CS}=$ Costa do Sauípe, $\mathrm{TU}=$ Tucano, $\mathrm{SE}=\mathrm{Serrinh}$. Means followed by the same letter, in the same column, do not differ significantly at $5 \%$ significance (Tukey Test).

The sensory profile of the honey samples evaluated for their various attributes (fluidity, color, aroma, crystallization, flavor, and acceptability) is presented graphically in Figure 2.

The center of the figure represents point zero in the scale used in the evaluation, while intensity increases from the center towards the edges. The sensory profile is thus revealed when the points are connected.

The results obtained in the present study indicate that honeys submitted to dehumidification do not undergo qualitative alterations and also present good acceptability. Consequently, taking into consideration the significant issue of stingless bee honey conservation resulting from its high moisture content, dehumidification emerges as a promising technique, preventing honey fermentation and consequent deterioration.

\section{ACKNOWLEDGMENTS}

The authors thank Conselho Nacional de Desenvolvimento Científico e Tecnológico (CNPq) and Fundação de Amparo à Pesquisa do Estado da Bahia (FAPESB) for partial financial support.

\section{RESUMO}

Este estudo foi conduzido com o objetivo de avaliar o efeito do processo de desumidificação sobre as características físicoquímicas e sensoriais do mel das abelhas sem ferrão. Amostras de méis de Melipona scutellaris e M. quadrifasciata foram submetidas ao processo de desumidificação, passando em seguida por avaliações físico-químicas (açúcares redutores, sacarose aparente, umidade, atividade diastásica, hidroximetilfurfural, cinzas, $\mathrm{pH}$, acidez e condutividade elétrica) e sensoriais (fluidez, cor, aroma, cristalização, sabor e aceitabilidade). Os resultados indicaram que o processo de desumidificação não interfere na qualidade e aceitabilidade do mel.

Palavras-chave: conservação de mel, meliponíneos, qualidade do mel, umidade.

\section{REFERENCES}

AOAC. 1990. Official methods of Analysis of AOAC International $\left(15^{\text {th }}\right.$ ed.). Arlington, Virginia, USA.

ATAGO Co. 1988. Refratômetro para mel. Abelhas, v. 31 (362/363), 9, 11-12, 41,44.

BOE. 1986. Orden de 12 de junio de 1986, de la Presidencia del Gobierno por la que se aprueban los métodos oficiales de analisis para la miel. B.O.E., Madrid, 18 junio. 145: 22195-22202.

BRASIL. 2000. Ministério da Agricultura. Instrução normativa $\mathrm{n}^{\circ} 11$, de 20 de outubro/2000. Regulamento técnico de identidade e qualidade do mel. (Available at: http://www.agricultura.gov.br/sda/dipoa/anexo).

Carvalho CAL, Sodré GS, Fonseca AAO, Silva SMPC, Oliveira GA and Clarton L. 2006. Perfil sensorial de amostras de méis de espécies de abelhas sem ferrão do Estado da Bahia. Magistra 18: 265-269. 
CAC. 1990. Official methods of analysis. 3(Suppl 2).

Crane E. 1987. Livro do mel. Trad de Astrid Kleinert Giovannini. São Paulo: Nobel, 226 p.

Fallico B, Zappalà M, Arena E and Verzera A. 2004. Effects of conditioning on HMF content in unifloral honeys. Food Chem 85: 305-313.

FERREIRA VLP (COORD). 2000. Análise sensorial - Testes discriminativos e afetivos. Campinas: Sociedade Brasileira de Ciência e Tecnologia de Alimentos, (Manual Série Qualidade), p. 73-77.

GaVA AJ. 1998. Princípios de tecnologia de alimentos. São Paulo: Nobel, 283 p.

Grosso GS. 2006. Criterios relativos al análisis sensorial de mieles. Apiservices - Galerie Virtuelle Apicole, França, Janeiro de 2006. (Available at: http://www.beekeeping.com/articulos/salamanca/index.htm).

Mardia LV, Keni JT And BibBy JM. 1979. Multivariate analysis. London: Academic Press, 521 p.

Moraes RM ANd Teixeira EW. 1998. Análise de mel. Pindamonhangaba, (Manual Técnico) $42 \mathrm{p}$.
Moraes RM, Benevides LHTS And Menezes A. 1989. A desumidificação no mel no Brasil. Apicultura \& Polinização 13: 27-29.

Pregnolato W and Pregnolato NP (Coord). 1985. Métodos químicos e físicos para análise de alimentos. Normas analíticas do Instituto Adolfo Lutz. Instituto Adolfo Lutz, São Paulo, SP, $3^{\text {a }}$ ed., 1: 533 p.

Silva JA. 2000. Tópicos de tecnologia de alimentos. São Paulo: Varela, $227 \mathrm{p}$

Soloveve TY. 1971. Determination of adulteration of honey on the basis of characteristics of honeys from single or multiple flower sources. Resumo em Apicultural Abstracts 22: 52-53.

White JÚnior JW. 1978. Honey. Adv Food Res 22: 287 374.

White JÚNIOR JW. 1994. The role of HMF and diastase assays in honey quality evaluation. Bee World 75: 104107. 